\title{
JUURNAL.RU
}

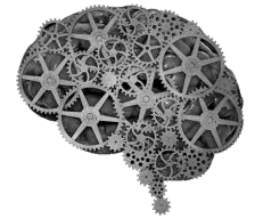

COMPANY GROUP "INTELLEKT"

\author{
Шахбанова А.C. \\ ДГУ \\ Махачкала, Россия
}

doi: 10.18411/lj2016-7-2-16

idsp 000001: lj2016-16-2-16

\section{Объективация концепта «время» в английском и русском языках}

Время и пространство являются основополагающими атрибутами нашего бытия, они не подвержены каким-либо объективным внешним изменениям. Но при всей стабильности экстралингвистической категории времени, лексические и стилистические средства выражения концепта времени претерпевают значительные изменения, связанные с субъективным восприятием человека. Претерпеваемые моделями времени изменения тем более радикальны, чем теснее связывается понятие времени с жизнью человека, его мироощущением и происходящими историческими процессами.

Таковыми причинами могут являться научный прогресс и соответствующее расширение знаний об окружающем мире: осознание человеком своей силы как равного Богу и принятие активной жизненной позиции, общее ускорение ритма жизни в связи с техническими достижениями и др.Следующие глаголы-действия самого времени - в совокупности с глаголами-действиями человека над временем позволяют сделать вывод о его свойствах. Время может:

1. прийти (come)

2. пройти (passe/ waste)

3. ускользать (stele for us)

4. пролетать (flee)

5. подкрадываться (crepe in)

6. приближаться (approche)

7. требовать (require) 
8. не может ждать (notabyde).

Данные сочетаемости позволяют выделить три условных метафорических блока:

1. время-путник: то, что движется;

2. время-господин: то, что требует, приказывает, не ждет;

3. время-имущество: то, чем обладают.

Первый метафорический блок указывает насамый очевидный факт - время длится: «Длительность есть настолько ясное и заметное свойство времени, что чаще всего оно отождествляется со временем. Неосознанно подразумевается, что длительность и время - это одно и то же, хотя... время более многоаспектное явление, чем длительность, а последнее есть нечто бесструктурное, беспрерывное, спонтанное, не имеющее ни начала, ни конца» [Аскольдов 1997: 270].

Исследование сочетаемостей времени-субъекта и времени-объекта в современном английском языке показало, что время можно:дать (give), оставлять (leave),провести (spend),потратить зря (waste),заполнить (fill),выбрать (chose),занять (take),купить (buy),иметь (have),в нем можно нуждаться (need),заставить двигаться (make... move),воспринимать как само собой разумеющеея (takeforgranted),в нем можно сориентироваться (discoveroneselfintime).

Анализ действий, производимых над временем, в современной английской литературе открывает перед нами нового человека, принимающего активную позицию по отношению к времени, способного определенным образом влиять на него. Человек, а также обстоятельства могут давать время, занимать, выбирать, наполнять, купить, оставить и даже заставить его двигаться, идти: Wehadhopedthatthismoon-threatwouldstopthewarforafewdays, andgivetheWorldSecurityCounciltimetoact (Уилсон),

Nothing is indescribable in words if you take the time and the trouble (Уилсон), Entirely without other occupation, she filled her time with household tasks and enjoyments (Мердок).

Лингвовременная картина мира объединяет концептуальный и языковой уровни: языковая временная семантика представляет собой с одной стороны, «оболочку» концепта «время», с другой - содержание по отношению к вербальному уровню. В качестве единицы лингвовременной картины мира 
выступает концепт «время». Одним из способов вербализации концепта «время» являются фразеологические единицы со значением «время». Временные представления в виде конкретных, ярких, чувственно-осязаемых зрительных и слуховых образов нашли отражение во внутренней форме фразеологизмов с временным значением. Именно во фразеологических единицах, которые составляют так называемую фразеологическую картину мира, искусственно созданную народом в процессе творчества, культурные концепты находят наиболее яркое отражение [Попова 2002: 25].

Лексема «время» в русском языке произошло от родственных слов «вертеть», «веретено». В русской картине мира, таким образом, идея времени связана с идеей повторяемости, регулярности, цикличности.Таким образом, русский язык отражает время, которое движется по кругу, циклично: «на майские», «К зимним», «на крещение». Согласно английскому подходу, время линейно, одномерно, однонаправленно и необратимо. Время движется, и его движение непрерывно. Каждое его мгновение уникально. Время нельзя остановить, повернуть вспять.Пунктуальность - одно из генетически связанных с английской нацией понятий. Точность является неотъемлемым атрибутом англичан, рассматривается ими как гарантия надежности, воспринимается в качестве способов противодействия непредсказуемости. В свою очередь, гиперчувствительное отношение ко времени в английской культуре не отвечает русским представлениям об его эффективном использовании: поживем - увидим; еще не вечер.

Для большинства русских, в отличие от англичан, время не является жестким принципом их жизни. Поэтому отношение к нему часто можно назвать легкомысленным, что находит отражение во всякого рода опозданиях, переносах мероприятий, не соблюдениях выполнения графиков движения самолетов, поездов и т.д.

Фразеологизмы, выражающие значение ирреального времени, являются самыми образными, экспрессивными, эмоциональными, так как их образность имеет двойственную природу: с одной стороны, они связаны с экстралингвистическими факторами (нереальностью ситуации, дающей простор безудержной фантазии), с другой - c лингвистическими факторами, проявляющимися в использовании для формирования образной структуры 
алогизмов, служащих самым ярким средством усиления образности, экспрессивности, выразительности, эмоциональности.

Наряду с фразеологизмами со значением «ирреальное время» объектом нашего исследования стали фразеологизмы со значением «реальное время», это настоящее время (в данный момент, сей момент, в данную минуту, inatrice), будущее время (на носу, не за горами, на пороге,soonerorlater, thesoonerthebetter, timetocome«будущие времена»), прошедшее время (в прадедах, в стариках, во времена оны,goodoldtime), а также время, представленное в лексических оппозициях, образно представленных в семантике фразеологизмов, связанных с параметрами измерения времени - «быстро - медленно» (молниеносно, глазом не успел моргнуть,bestpartofanhour, flewlikeaboltoflightning, onthespurofthemoment, offthetopofone’shead), «рано - поздно» (ни свет, ни заря; до глубокой ночи; longbeforedawn; adaybeforethefair, atthepeepofday, withthelark (withthesun), atthefirsthintofday).

Абстрактное понятие «всегда», отображенное во фразеологизмах английского и русского языков, имеет некую поэтическую возвышенность и обладает, в основном, положительной окраской в обоих языках. Обычно такие фразеологизмы относятся к теме дружбы, любви, благодарности и ненависти (до скончания века, во веки веков, на веки вечные, tillthecowscomehome, tothegrave, tothetomb). Фразеологизмы с понятием «никогда» и русском, и в английском языках чаще имеют отрицательную коннотацию (доновыхвениковнезабудет, нинамиг, ниподкакимпредлогом, never for a moment, not for a minute, on no account, under the circumstances). Фразеологизмы со значением «никогда» чаще встречаются в английском языке и имеют более яркую образность в силу того, что англичане более категоричные и принципиальные, чем русские.

В обеих культурах присутствует осознание того, что все быстротечно и всему есть свой предел (долго ли до греха (беды), ничто не вечно под луной, troubleisneverfaroff, thereisnothingpermanentunderthemoon, themorningsunneverlastsaday).

Исходя из полученных в ходе исследования данных, можно сделать вывод, что в основе языкового воплощения концепта «время» и в английской, и в русской лингвокультурах, помимо универсальных черт, лежат и национальноспецифические особенности, которые обусловлены различием английской и 
русской социальных культур, отразивших особенности менталитета и системы ценностей двух национальных сообществ. Как правило, прежде всего, фразеологизмы, внутренняя форма которых построена на алогизме, обладают национальной спецификой, отражающей особенности восприятия времени русским и английским народами.

\section{Литература:}

1. Аскольдов С.А. Концепт и слово // Русская словесность. От теории словесности к структуре текста: Антология / Под общ.ред. В.П. Нерознака. М., 1997. С. 267-279.

2. Аракин А.Д. История английского языка. М., 1978.

3. Кунин А.В. Фразеология современного английского языка. М., 2000.

4. Логический анализ языка. Культурные концепты. / Отв. ред. Н.Д. Арутюнова. М., 1991.

5. Попова З.Д., Стернин И.А. Очерки по когнитивной лингвистике. Воронеж, 2002. 